\title{
Article \\ Use of Digestate as Organic Amendment and Source of Nitrogen to Vegetable Crops
}

\author{
Carmo Horta ${ }^{1,2, *(D)}$ and João Paulo Carneiro ${ }^{1,2}$ (D) \\ 1 Polytechnic Institute of Castelo Branco, School of Agriculture, Quinta da Sra. de Mércules, \\ 6001-909 Castelo Branco, Portugal; jpc@ipcb.pt \\ 2 CERNAS-IPCB Research Centre for Natural Resources, Environment and Society, Polytechnic Institute of \\ Castelo Branco, 6001-909 Castelo Branco, Portugal \\ * Correspondence: carmoh@ipcb.pt; Tel.: +351-272-339-900; Fax: +351-272-339-901
}

Citation: Horta, C.; Carneiro, J.P. Use of Digestate as Organic

Amendment and Source of Nitrogen to Vegetable Crops. Appl. Sci. 2022, 12, 248. https://doi.org/10.3390/ app12010248

Academic Editor: Michael Kornaros

Received: 25 November 2021

Accepted: 23 December 2021

Published: 27 December 2021

Publisher's Note: MDPI stays neutral with regard to jurisdictional claims in published maps and institutional affiliations.

Copyright: (c) 2021 by the authors. Licensee MDPI, Basel, Switzerland. This article is an open access article distributed under the terms and conditions of the Creative Commons Attribution (CC BY) license (https:/ / creativecommons.org/licenses/by/ $4.0 /)$.

\begin{abstract}
Anaerobic digestion is a valuable process to use livestock effluents to produce green energy and a by-product called digestate with fertilising value. This work aimed at evaluating the fertilising value of the solid fraction (SF) of a digestate as an organic amendment and as a source of nitrogen to crops replacing mineral N. A field experiment was done with two consecutive vegetable crops. The treatments were: a control without fertilisation; Ni85 mineral fertilisation with $85 \mathrm{~kg} \mathrm{ha}^{-1}$ of mineral $\mathrm{N}$; fertiliser with digestate at an increasing nitrogen application rate $\left(\mathrm{kg} \mathrm{N} \mathrm{ha}^{-1}\right)$ : DG-N85 DG-N170, DG-N170+85, DG-N170+170; fertilisation with digestate together with Ni: DG-N85+Ni60, DG-N170+Ni60, DG-N170+Ni25. The results showed a soil organic amendment effect of the SF with a beneficial effect on SOM, soil $\mathrm{pH}$ and exchangeable bases. The SF was able to replace part of the mineral $\mathrm{N}$ fertilisation. The low mineralisation of the stable organic matter together with some immobilisation of mineral $\mathrm{N}$ from SF caused low $\mathrm{N}$ availability. The fertilisation planning should consider the SF ratio between the organic $\mathrm{N}(\mathrm{NO})$ and total $\mathrm{N}(\mathrm{TKN})$. Low NO:TKN ratios $(\approx 0.65)$ needed lower $\mathrm{Ni}$ addition to maintaining the biomass production similar to the mineral fertilisation.
\end{abstract}

Keywords: anaerobic digestion; circular economy; green energy; $\mathrm{N}$ use efficiency; short carbon cycle

\section{Introduction}

The anaerobic digestion of livestock effluents is considered valuable since it adds value to slurries since the process provides biogas $\left(45-85 \% \mathrm{CH}_{4}\right.$ and $\left.25-50 \% \mathrm{CO}_{2}\right)$ as a renewable energy source and digestate with fertilising value to agricultural soils. The anaerobic digestion also contributes to the "short carbon cycle", ensuring carbon removal from the atmosphere. Thus, anaerobic digestion provides the carbon from the organic residues to produce biogas and continues with reusing the carbon contained in the digestate, putting it back in the soil. The whole carbon cycle is completed by valorising the carbon dioxide after producing biomethane, obtained after removing the carbon dioxide and trace gases from the biogas. The use of biogas and biomethane as renewable energy sources are essential to accelerate the reduction of GHG emissions (e.g., $\mathrm{CO}_{2}$ and $\mathrm{CH}_{4}$ ), namely in agriculture and livestock activities, meet the renewable energy demand by 2030 and achieve climate targets in 2050 [1-3]. Europe is the largest producer of biogas and biomethane in the world today [4]. Globally in 2040, over 1000 Mtoe of biomethane can be potentially produced, with average costs falling by $15 \%$ in relation to costs in $2018[3,4]$. Therefore, the use of digestate as a biofertiliser will increase in the near future, contributing to the circular economy in agriculture, reducing demand for the carbon-intensive production of mineral fertilisers. The agronomic role of digestate is well recognised in several works in which its effect as a soil amendment increasing the level of the soil organic matter (SOM) [5-7] and also its role as a source of nutrients, namely N, P and K [8-11] is reported. However, more profound knowledge is needed regarding the agronomic behaviour of digestates as a source of $\mathrm{N}$ to crops. In the EU, a low-cost and straightforward treatment of the digestate is widely 
used to achieve a solid/liquid (S/L) separation by press screw, allowing the production of two fractions with different characteristics. After S/L separation, the liquid fraction (LF) contain the majority of the total Kjeldahl nitrogen (TKN) of the digestate with values around $87 \%$ [12] and with an average content $(n=11)$ of $97.5 \mathrm{~g} \mathrm{TKN} \mathrm{kg}^{-1} \mathrm{DM}$ which is mainly $(61 \%)$ in the available $\mathrm{N}-\mathrm{NH}_{4}$ (TAN) mineral form [13]. These authors concluded that the LF could be used as a substitute for $\mathrm{N}$ mineral fertilisers, and the solid fraction (SF) can be proposed as an NP-organic fertiliser. They also observed high variability in the TKN and the TAN:TKN ratio of the solid fraction of the digestates reporting TKN values $(n=13)$ between 124 and $73 \mathrm{~g} \mathrm{~kg}^{-1} \mathrm{DM}$ and TAN:TKN ratio values between 72 and $39 \%$. Therefore, these results suggested that the SF can have a different ability to release $\mathrm{N}$ to crops, resulting from the proportion between their mineral and organic $\mathrm{N}$ forms.

We hypothesised that the net $\mathrm{N}$ release to crops from the SF will be influenced not only by its content in mineral N (TAN:TKN ratio) but also by the TKN partition between mineral and organic forms causing differences in the balance between the immobilisation/mineralisation of the TKN.

This work aimed to assess the fertilising value of two digestates with different NO:TKN ratios as organic amendments and as sources of $\mathrm{N}$ replacing $\mathrm{N}$ mineral fertilisers in a field experiment with two successive vegetable crops.

\section{Materials and Methods}

\subsection{Site Description and Experimental Design}

The field study was conducted at an experimental area of vegetable crops on a farm belonging to the Polytechnic Institute of Castelo Branco (39.823655, -7.451606 Decimal Degrees, WGS 84 coordinates). The soil is a Dystric Cambisol [14] developed from granitic rocks. The region has a temperate climate with dry summer (Csa, Köppen classification) with a mean annual temperature of $15.0^{\circ} \mathrm{C}$, a mean maximum and minimum temperatures of 21.5 and $9.4^{\circ} \mathrm{C}$, respectively, and mean annual rainfall of $735 \mathrm{~mm}$ [15].

This trial was conducted during 2020-2021 with two successive vegetable crops, lettuce (Lactuca sativa L.) and kale (Brassica oleracea var. Winterborn). Lettuce is a salinity sensitive crop with a high ability to uptake heavy metals accumulated in its leaves. So, it is an appropriate crop to assess the entry of toxic elements in the food chain and changes in soil fertility.

The experimental design for the two vegetable crops was completed randomised with 9 treatments, each one with 4 replicates with 36 plots. Each plot (replicate) had $1.08 \mathrm{~m}^{2}$ $(1.20 \times 0.90 \mathrm{~m})$ with 12 lettuces. The lettuces had a row spacing of $0.30 \mathrm{~m}$, and in the row, the distance between two lettuces was $0.30 \mathrm{~m}$. The lettuce seedlings were planted on 6 March 2020 and harvested on 7 May 2020 with a crop cycle of 62 days. In February, before planting, the soil was harvested and milled, then the digestate was incorporated manually into the soil, and the plots were watered. For 11 days, the soil with the digestate was left to rest. The mineral nitrogen fertiliser was applied two days before seedling and incorporated into the soil manually. The top-dressing nitrogen fertilisation using the mineral fertiliser was done twice after 22 and 49 days after planting. During the lettuce crop cycle, the average temperature was $13{ }^{\circ} \mathrm{C}$ and the rainfall $250 \mathrm{~mm}$, and for the kale crop cycle was $10{ }^{\circ} \mathrm{C}$ and $500 \mathrm{~mm}$, respectively. Concerning the kale experiment, the agricultural practices were the same as the lettuce. However, the plants had a row spacing of $0.35 \mathrm{~m}$ and a distance between two kale plants of $0.35 \mathrm{~m}$. The kale seedlings were planted on 15 October 2020 and harvested on 16 March 2021 with a crop cycle of 152 days. The top-dressing nitrogen fertilisation using the mineral fertiliser was done twice, 61 and 120 days after planting. In the lettuce trial, ammonium nitrate $(27 \% \mathrm{Ni})$ was used for the Ni basal fertilisation, and for the first top-dressing and calcium nitrate $(15.5 \% \mathrm{Ni})$ was used, in the second top-dressing $\mathrm{Ni}$ fertilisation. In the kale trial, ammonium sulphate $(20.5 \% \mathrm{Ni})$ was used for the $\mathrm{Ni}$ basal fertilisation and for the first top-dressing and for the second top-dressing ammonium nitrate $(27 \% \mathrm{Ni})$ was used. The fertilisers with the ammoniacal form of $\mathrm{N}$ were used to avoid $\mathrm{N}$ leaching whenever the probability of rain was high. 
The treatments were the same for the two crops. Since the soil had high levels of phosphorus (149 $\mathrm{mg} \mathrm{P} \mathrm{kg}^{-1}$ evaluated by the method of Olsen et al. [16]) and of potassium (530 $\mathrm{mg} \mathrm{K} \mathrm{kg}^{-1}$ evaluated by the method of Egnér et al. [17]), only the nitrogen mineral fertilisation was done (Table 1 ).

Table 1. Treatments and fertilisation done during the field experiments with lettuce and kale.

\begin{tabular}{|c|c|c|c|c|c|c|}
\hline \multirow[t]{2}{*}{ Treatments } & \multicolumn{3}{|c|}{ Lettuce } & \multicolumn{3}{|c|}{ Kale } \\
\hline & Before Planting & $\begin{array}{c}\text { 1st } \\
\text { Top-Dressing }\end{array}$ & $\begin{array}{c}\text { 2nd } \\
\text { Top-Dressing }\end{array}$ & $\begin{array}{l}\text { Before } \\
\text { Planting }\end{array}$ & $\begin{array}{c}1 \text { st } \\
\text { Top-Dressing }\end{array}$ & $\begin{array}{c}\text { 2nd } \\
\text { Top-Dressing }\end{array}$ \\
\hline & $\begin{array}{c}\text { February } \\
2020\end{array}$ & $\begin{array}{l}\text { March } \\
2020\end{array}$ & $\begin{array}{c}\text { April } \\
2020\end{array}$ & $\begin{array}{c}\text { October } \\
2020\end{array}$ & December 2020 & February 2021 \\
\hline & \multicolumn{6}{|c|}{$\operatorname{kg~N~ha~}^{-1}$} \\
\hline Control & 0 & 0 & 0 & 0 & 0 & 0 \\
\hline \multirow[t]{2}{*}{ Ni85 } & Ni35 & $\mathrm{Ni} 25$ & $\mathrm{Ni} 25$ & Ni35 & $\mathrm{Ni} 25$ & $\mathrm{Ni} 25$ \\
\hline & CAN & CAN & $\mathrm{CN}$ & AS & AS & CAN \\
\hline DG-N85 & DG-85 & 0 & 0 & DG-85 & 0 & 0 \\
\hline DG-N170 & DG-170 & 0 & 0 & DG-170 & 0 & 0 \\
\hline DG-N170+85 & DG-170+85 & 0 & 0 & DG-170+85 & 0 & 0 \\
\hline DG-N170+170 & DG-170+170 & 0 & 0 & DG-170+170 & 0 & 0 \\
\hline \multirow[t]{2}{*}{ DG-N85+Ni60 } & DG-85+Ni35 & $\mathrm{Ni} 25$ & 0 & DG-85+Ni35 & Ni25 & 0 \\
\hline & DG+CAN & CAN & & DG+AS & AS & \\
\hline \multirow[t]{2}{*}{ DG-N170+Ni60 } & DG-170+Ni35 & $\mathrm{Ni} 25$ & 0 & DG-170+Ni35 & $\mathrm{Ni} 25$ & 0 \\
\hline & DG+CAN & CAN & & DG+AS & AS & \\
\hline \multirow[t]{2}{*}{ DG-N170+Ni25 } & DG-170 & $\mathrm{Ni} 25$ & 0 & DG-170 & $\mathrm{Ni} 25$ & 0 \\
\hline & & CAN & & & AS & \\
\hline
\end{tabular}

CAN-calcium ammonium nitrate $(27 \% \mathrm{Ni}) ; \mathrm{CN}-$ calcium nitrate $(15.5 \% \mathrm{Ni})$; AS-ammonium sulphate $(20.5 \% \mathrm{Ni})$

The nine treatments done in the experiments were: a control without any fertilisation (control); mineral $\mathrm{N}$ fertilisation with an $\mathrm{N}$ application rate of $35 \mathrm{~kg} \mathrm{~N}^{-1}$ before seedling planting, and $25 \mathrm{~kg} \mathrm{~N} \mathrm{ha}^{-1}$ in each top-dressing with a total application of $85 \mathrm{~kg} \mathrm{ha}^{-1}$ of inorganic $\mathrm{N}$ (Ni85). This amount of $\mathrm{N}$ is the reference fertilisation used for both crops [18]; application of an amount of digestate corresponding to $85 \mathrm{~kg} \mathrm{ha}^{-1}$ of $\mathrm{N}$ (TKN) from the solid fraction of the digestate before seedling planting (DG-N85); application of an amount of digestate corresponding to $170 \mathrm{~kg}$ of $\mathrm{N} \mathrm{ha}^{-1}$ before seedling planting (DG-N170); application of an amount of digestate corresponding to $170+85 \mathrm{~kg}$ of $\mathrm{N} \mathrm{ha}^{-1}$ before seedling planting (DG-N170+85); application of an amount of digestate corresponding to $170+170 \mathrm{~kg}$ of $\mathrm{N}^{-1}$ before seedling planting (DG-N170+170); application of an amount of digestate corresponding to 85 of $\mathrm{N} \mathrm{ha}^{-1}$ plus $35 \mathrm{~kg}$ of mineral nitrogen before seedling planting and at the first $\mathrm{N}$ top-dressing, $25 \mathrm{~kg} \mathrm{Ni} \mathrm{ha}^{-1}$ (DG-N85+Ni60); application of an amount of digestate corresponding to 170 of $\mathrm{N} \mathrm{ha}^{-1}$ plus $35 \mathrm{~kg}$ of mineral nitrogen before seedling planting and at the first $\mathrm{N}$ top-dressing, $25 \mathrm{~kg} \mathrm{Ni} \mathrm{ha}^{-1}$ (DG-N170+Ni60); application of an amount of digestate corresponding to 170 of $\mathrm{N} \mathrm{ha}^{-1}$ before seedling planting and at the first $\mathrm{N}$ top-dressing, $25 \mathrm{~kg} \mathrm{Ni} \mathrm{ha}^{-1}$ (DG-N170+Ni25).

\subsection{Analysis}

\subsubsection{Digestate}

The digestate used in this work was obtained at a biogas plant from a mixture of pig slurry and cereal straw during 30 days of retention time in mesophilic reactors with $3000 \mathrm{~m}^{3}$ of capacity. Then, the digestate slurry was pressed to separate the solid and the liquid phases. In this work, we used only the solid fraction of the digestate.

The solid fraction of the digestate was characterised for moisture content by the gravimetric method; $\mathrm{pH}$ was determined with a glass electrode (organic amendment to water ratio of 1:5, CRISON micropH 2002, Barcelona, Spain) and electrical conductivity 
with a conductivimeter in a 1:10 suspension (SF:water ratio). Organic matter was quantified by losing weight after ignition at $550{ }^{\circ} \mathrm{C}$ for $16 \mathrm{~h}$ (Controller B 180, Naberthem, Lilienthal, Germany). The Kjeldahl procedure evaluated total N (TKN) and organic (NO). Total P (PT) was determined after ignition at $550{ }^{\circ} \mathrm{C}$ for $3 \mathrm{~h}$ and extracted with $\mathrm{H}_{2} \mathrm{SO}_{4} 0.5 \mathrm{M}$, inorganic $\mathrm{P}(\mathrm{Pi})$ was extracted with $\mathrm{H}_{2} \mathrm{SO}_{4} 0.5 \mathrm{M}$ and then quantified by molecular absorption spectrophotometry (spectrophotometer Thermo Electron Corporation evolution 300 LC, Waltham, MA, USA). Organic P (Po) was calculated as the difference between PT and Pi. All the $P$ in the extracts were centrifugated at $3000 \mathrm{rpm}$, and $\mathrm{P}$ in the supernatant was quantified by the method of Murphy and Riley [19].

Total cations such as $\mathrm{Fe}, \mathrm{Mn}, \mathrm{Cu}, \mathrm{Pb}, \mathrm{Cd}$ and $\mathrm{Cr}$ were also extracted by the aqua regia digestion and quantified by atomic absorption spectrophotometry. Total $\mathrm{K}, \mathrm{Ca}, \mathrm{Mg}$ and $\mathrm{Na}$ were quantified by flame emission spectrophotometry ( $\mathrm{K}$ and $\mathrm{Na}$ ) and atomic absorption spectrophotometry (Ca and Mg) (Thermo Scientific Series iCE 3000, Waltham, MA, USA), from the hydrochloric acid solution of the ashes obtained by the organic amendment's ignition at $550{ }^{\circ} \mathrm{C}$.

The chemical composition of the solid digestates used in the lettuce (DGL) and the kale (DGK) experiments are shown in Table 2.

Table 2. Chemical composition of the solid fraction of the anaerobic digestates used in the field experiments. DGL was the digestate used in the lettuce experiment, and DGK was the digestate used in the kale experiment.

\begin{tabular}{ccc}
\hline & DGL & DGK \\
\hline${ }^{1} \mathrm{DM} \mathrm{g} \mathrm{kg}^{-1}$ & 282 & 248 \\
${ }^{2} \mathrm{OM} \mathrm{g} \mathrm{kg}^{-1}$ & 637 & 761 \\
$\mathrm{pH}$ & 7.7 & 8.3 \\
$\mathrm{EC} \mathrm{dS} \mathrm{m}{ }^{-1}$ & 1.5 & 1.3 \\
${ }^{3} \mathrm{NO} \mathrm{g} \mathrm{kg}^{-1}$ & 19.3 & 24.1 \\
$4 \mathrm{TKN}^{\mathrm{CN}}$ & 29.7 & 29.7 \\
$\mathrm{PT} \mathrm{g} \mathrm{kg}^{-1}$ & 12 & 15 \\
$\mathrm{Pi} \mathrm{g} \mathrm{kg}^{-1}$ & 4.8 & 7.1 \\
$\mathrm{Po} \mathrm{g} \mathrm{kg}^{-1}$ & 4.5 & 6.8 \\
$\mathrm{WSP} \mathrm{g} \mathrm{kg}^{-1}$ & 0.3 & 0.3 \\
$\mathrm{~K} \mathrm{~g} \mathrm{~kg}^{-1}$ & 2 & 2.5 \\
\hline
\end{tabular}

All the parameters analysed in the digestate are expressed on a dry matter basis, excluding $\mathrm{pH}$ and CE. ${ }^{1} \mathrm{DM}-\mathrm{dry}$ matter; ${ }^{2} \mathrm{OM} \longrightarrow$ organic matter; ${ }^{3} \mathrm{NO}-$ organic $\mathrm{N} ;{ }^{4} \mathrm{TKN}$-total $\mathrm{N}$.

The standards of some European countries [20-22] specify for products to be considered as soil amendments (those that have a beneficial effect on soil OM) an OM content between 20 and $90 \%$ on a DM basis; they should have a dry matter content higher than 30-50\% [22,23] and a C/N ratio higher than eight [23]. So, overall the digestates meet these standards except for the dry matter content slightly below the minimum threshold level (29 and 25\%). Additionally, the electrical conductivity (EC of 1.5 and $1.3 \mathrm{dS} \mathrm{m}^{-1}$ ) of the digestate was within the normal range to prevent soil salinity, considering that $3 \mathrm{dS} \mathrm{m}^{-1}$ is the threshold value [24]. Regarding the N content, DG had almost 3\% of total N. However, the proportion of $\mathrm{N}$ in organic forms is different between the DG used in the lettuce and the kale experiments. In the lettuce experiment, the organic forms of $\mathrm{N}(\mathrm{NO})$ accounted for $65 \%$ and in the kale accounted for $81 \%$ of the total $N$ (TKN), the remaining proportion being the mineral $\mathrm{N}(\mathrm{Nm})$ forms.

The treatments with DG that applied an amount of mineral $\mathrm{N}\left(\mathrm{N}_{\mathrm{m}}\right)$ similar to the Ni treatment (85 kg ha ${ }^{-1}$; Table 3) were: for lettuce, the DG-170+85, DG-85+Ni60 and DG-N170+Ni25 and for kale DG-N170+Ni60. 
Table 3. Amount of $\mathrm{N}$ applied to soil in the different treatments through mineral $\left(\mathrm{N}_{\mathrm{m}}\right)$ and organic (NO) forms.

\begin{tabular}{|c|c|c|c|c|}
\hline \multirow{3}{*}{$\begin{array}{c}\text { Treatment } \\
\text { Experiment }\end{array}$} & \multicolumn{2}{|c|}{ Lettuce } & \multirow{2}{*}{\multicolumn{2}{|c|}{$\begin{array}{l}\text { Kale } \\
\text { TKN }\end{array}$}} \\
\hline & \multicolumn{2}{|c|}{ TKN } & & \\
\hline & 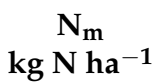 & $\begin{array}{c}\text { NO } \\
\operatorname{kg} \mathrm{N} \mathrm{ha}^{-1}\end{array}$ & $\begin{array}{c}N_{\mathrm{m}} \\
\operatorname{kg~N~ha-1}^{-1}\end{array}$ & $\begin{array}{c}\mathrm{NO} \\
\operatorname{kg} \mathrm{Nha}^{-1}\end{array}$ \\
\hline Control & 0 & 0 & 0 & 0 \\
\hline Ni85 & 85 & 0 & 85 & 0 \\
\hline DG-N85 & 30 & 55 & 16 & 69 \\
\hline DG-N170 & 59 & 111 & 32 & 138 \\
\hline DG-N170+85 & 89 & 166 & 48 & 207 \\
\hline DG-N170+170 & 119 & 221 & 65 & 275 \\
\hline DG-N85+Ni60 & 90 & 55 & 76 & 69 \\
\hline DG-N170+Ni60 & 119 & 111 & 92 & 138 \\
\hline DG-N170+Ni25 & 84 & 111 & 57 & 138 \\
\hline
\end{tabular}

TKN—total nitrogen; $\mathrm{N}_{\mathrm{m}}$-mineral $\mathrm{N}$ from mineral fertilisers or $\mathrm{DG} ; \mathrm{NO}-\mathrm{N}$ in organic forms from $\mathrm{DG}$.

The total $\mathrm{P}$ content of the digestates (4.8 and $7.1 \mathrm{~g} \mathrm{~kg}^{-1}$ ) was within the range (2-35 $\left.\mathrm{g} \mathrm{kg}^{-1}\right)$ referred by other works [25-27]. The digestates had 94 and $96 \%$ of their total P inorganic P forms. The WSP of DG (2.0 and $2.5 \mathrm{~g} \mathrm{~kg}^{-1}$ ) were lower than that referred by García-Albacete et al. [28] for digestate obtained from municipal solid wastes $\left(3.6 \mathrm{~g} \mathrm{~kg}^{-1}\right)$. The levels of other nutrients in DG such as $\mathrm{Cu}, \mathrm{Zn}$ Fe and Mn and non-nutrient such as Cd, $\mathrm{Cr}$ and $\mathrm{Pb}$ (data not shown) were below the threshold levels of the Portuguese legislation for composts [22].

Concerning the microbiological analysis, the digestates were free of microorganisms of faecal origin, such as Escherichia coli which had $6.5 \times 102 \mathrm{CFU} \mathrm{g}^{-1}$ and Salmonella spp., which was not detected. These values are also in accordance with the legislation mentioned above [22]. Overall, the digestates meet the quality requirements criteria defined by the European Union [29].

\subsubsection{Soil}

Before the experiment in February 2020, an initial composite soil sample of the area was taken. At the end of the experiments in May 2020 and in March 2021, composite soil samples were taken from each plot from $0-0.20 \mathrm{~m}$ of depth. Soil samples were air-dried, sieved $(<2 \mathrm{~mm})$ analysed for $\mathrm{pH}\left(\mathrm{H}_{2} \mathrm{O}\right)$, electrical conductivity $(\mathrm{EC})$, organic matter $(\mathrm{OM})$, textural class and Olsen $\mathrm{P}$. The $\mathrm{pH}$ was measured using a $\mathrm{pH}$ electrode (CRISON micropH 2002, Barcelona, Spain) by taking $10.0 \mathrm{~g}$ of dried and sieved soil and $25 \mathrm{~mL}$ of distilled water (1:2.5 soil:solution ratio) which were in contact for $1 \mathrm{~h}$. The EC was measured with a conductivimeter at a soil:water suspension ratio of 1:2 after $60 \mathrm{~min}$ of shaking. According to the procedure described by Walkley and Black, the organic matter was analysed using a potentiometric titration method (HI 901 C1, HANNA Instruments, Woonsocket, RI, USA), [30]. The soil texture was evaluated by the particle size analysis using the pipetting method [31]. Crop available potassium was quantified by Egnér et al. [17]. The Olsen $\mathrm{P}$ [16] was used to evaluate the available soil $\mathrm{P}$. The orthophosphate $\mathrm{P}$ in the solution was determined by the molybdate blue method of Murphy and Riley (spectrophotometer Thermo Electron Corporation evolution 300 LC, Waltham, MA, USA), [19].

The soil was sandy loam, and at the beginning of the experiment (Table 4), it was slightly acidic, high in OM, high in $\mathrm{P}$ and very high in $\mathrm{K}$, with a high capacity of exchangeable cations, medium level of exchangeable $\mathrm{Ca}$, low in $\mathrm{Mg}$ and very low in $\mathrm{Na}$ [18]. 
Table 4. Background soil properties (February 2020, $n=3$, average \pm SD).

\begin{tabular}{|c|c|c|c|c|c|c|c|c|c|}
\hline $\mathrm{pH}$ & ${ }^{1} \mathrm{OM}$ & ${ }^{2}$ CEC & $\mathrm{Ca}^{2+}$ & $\mathrm{Mg}^{2+}$ & $\mathrm{Na}^{2+}$ & $\mathrm{K}^{+}$ & Olsen P & $\mathbf{P i}$ & Po \\
\hline & $\%$ & & \multicolumn{2}{|c|}{$\mathrm{cmol}_{\mathrm{c}} \mathrm{kg}^{-1}$} & \multicolumn{5}{|c|}{$\mathrm{mg} \mathrm{kg}^{-1}$} \\
\hline $\begin{array}{c}6.4 \\
( \pm 0.04)\end{array}$ & $\begin{array}{c}5.4 \\
( \pm 0.05)\end{array}$ & $\begin{array}{c}36.9 \\
( \pm 3.81)\end{array}$ & $\begin{array}{c}7.30 \\
( \pm 0.17)\end{array}$ & $\begin{array}{c}0.90 \\
( \pm 0.02)\end{array}$ & $\begin{array}{c}0.02 \\
( \pm 0.005)\end{array}$ & $\begin{array}{c}1.37 \\
( \pm 0.17)\end{array}$ & $\begin{array}{c}149 \\
( \pm 11)\end{array}$ & $\begin{array}{c}663 \\
( \pm 59)\end{array}$ & $\begin{array}{c}373 \\
( \pm 21)\end{array}$ \\
\hline
\end{tabular}

\subsubsection{Vegetable Crops}

Four lettuce or kale plants were cut in the central part of each plot (replicate) and weighed to quantify the biomass production (fresh matter). Then they were dried at $65^{\circ} \mathrm{C}$ for $48 \mathrm{~h}$ and weighed again to quantify crop yield on a dry matter production basis. Nitrogen was quantified by the Kjeldahl procedure (Nk) before drying the lettuce or the kale plants, and the result was expressed on a DM basis.

The nitrogen use efficiency (NUE) by the crops was evaluated by different indexes such as the $\mathrm{N}$ recovery efficiency (NRE), the $\mathrm{N}$ agronomic efficiency (NAE) and the $\mathrm{N}$ partial productivity (NPP). These indexes were calculated using the following equations:

$$
\begin{gathered}
\mathrm{N} \text { recovery efficiency }(\%)=\frac{(\text { NNuptake }- \text { NOuptake })}{\mathrm{FN}} \times 100 \\
\mathrm{~N} \text { agronomic efficiency }\left(\mathrm{g} \text { DMY g }{ }^{-1} \mathrm{~N}\right)=\frac{(\text { DMYN-DMY0 })}{\mathrm{FN}} \\
\mathrm{N} \text { partial productivity }\left(\mathrm{g} \mathrm{DM} \mathrm{g}^{-1} \mathrm{~N}\right)=\frac{\mathrm{DMYN}}{\mathrm{FN}}
\end{gathered}
$$

$\mathrm{N}$ uptake $\left(\mathrm{g} \mathrm{N} \mathrm{m}^{-2}\right.$ ) is the amount of $\mathrm{N}$ uptake by the crops in the $\mathrm{N}$ fertilised plots, and NOuptake is the amount of $\mathrm{N}$ uptake in the control plot (without $\mathrm{N}$ fertilisation). The DMYN $\left(\mathrm{g} \mathrm{DM} \mathrm{m}^{-2}\right.$ ) is the dry matter yield of the crops in the $\mathrm{N}$ fertilised plots, and DMY0 is the dry matter yield in the control plot. FN is the amount of $\mathrm{N}$ applied $\left(\mathrm{g} \mathrm{N} \mathrm{m}^{-2}\right)$.

The NRE and NAE indexes were done with the amount of TKN applied to the soil with the digestate and the amount of the $\mathrm{N}$ mineral applied with the digestate, as shown in Table 3. In this last case, the indexes are $\mathrm{N}_{\mathrm{m}} \mathrm{RE}$ and $\mathrm{N}_{\mathrm{m}} \mathrm{AE}$.

NUE was also evaluated by the biomass production (fresh matter, $\mathrm{g} \mathrm{m}^{-2}$ ) and by the $\mathrm{N}$ relative yield (RY) calculated by the following equation:

$$
\text { Relative yield }(\%)=\left[\frac{\mathrm{FMY}}{\mathrm{FMYNi}}\right] \times 100
$$

where FMY $\left(\mathrm{g} \mathrm{m}^{-2}\right)$ is the biomass (fresh matter yield) produced by each treatment with digestate application or by the control treatment, and FMNi is the biomass (fresh matter yield) produced by the treatment with only mineral nitrogen fertilisation (Ni85).

\subsection{Statistical Analyses}

Statistical analysis of the data was carried out with IBM SPSS statistics 26.0 software (IBM SPSS Statistics for Windows, Version 26.0, Armonk, NY, USA). Data were tested for normality using the Shapiro-Wilk test. The comparison of soil properties after the two crop cycles were done by ANCOVA, using the general linear model/univariate analysis with the treatments (nine treatments) as a factor and the year as the covariate variable. The LSD test was used to compare means at 0.05 probability level. The results for each crop cycle regarding the biomass production and the nitrogen use efficiency indexes, for the comparisons between the treatments, were analysed by the one-way ANOVA. The Duncan test was used to compare means at 0.05 probability level. 


\section{Results}

\subsection{Biomass and Nitrogen Use Efficiency Indexes}

The biomass production (fresh matter yield) of each vegetable crop showed significant differences between the treatments (Figure $1 \mathrm{a}, \mathrm{b} ; p<0.001$ ). The biomass (FMY) of the lettuce ranged from $3544 \mathrm{~g} \mathrm{~m}^{-2}$ in treatment $\mathrm{C}$ to $\cong 6000 \mathrm{~g} \mathrm{~m}^{-2}$ in DG-N85+Ni60 and DG-N170+Ni60. The biomass production of kale ranged between 1175 to $2157 \mathrm{~g} \mathrm{~m}^{-2}$ in C and DG-N170+Ni60 treatments, respectively.
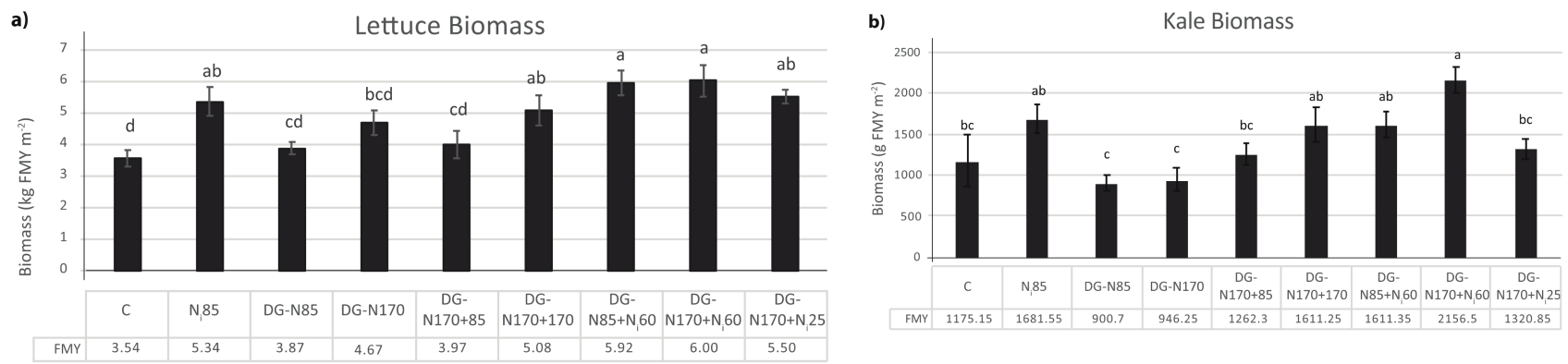

Figure 1. Biomass production of (a) lettuce $\left(\mathrm{kg} \mathrm{FMY} \mathrm{m}^{-2}\right)$ and (b) kale $\left(\mathrm{g} \mathrm{FMY} \mathrm{m}^{-2}\right)$. According to Duncan's multiple range test, different letters above the columns indicate statistically significant differences among the treatments $(p<0.05)$. The data are presented as mean $\pm \operatorname{SE}(n=4)$.

Overall there is a decrease in the relative yield (Equation (4)) of both crops in the plots with DG application as the only source of $\mathrm{N}$. The two crops showed significant differences in the RY between the treatments $(p<0.001)$. However, lettuce and kale responded differently in their RY regarding the application of DG. In the case of the lettuce, the relative yield ranged from $72-74 \%$ in DG-N85 and DG-N170+85 to $111-112 \%$ in DG-N85+Ni60 and DG-N170+Ni60 treatments. The kale crop showed a more profound decrease of the RY in the DG treatments compared with the lettuce crop. Thus, the relative yield of kale decreased 54-56\% in DG-N85 and DG-N170 (in these two treatments, the RY was even lower than in the control) but increased to $128 \%$ in the DG-N170+Ni60. We can also observe that the lettuce biomass and RY of the DG-N85 and DG-N170+85 treatments showed statistically similar values to the control and were significantly lower than the Ni85 treatment. The same trend was observed in the DG-N85 and DG-N170 treatments of the kale experiment. It is worth noting that for lettuce, the DG-N170+85 treatment applied same amount of mineral $\mathrm{N}\left(\mathrm{N}_{\mathrm{m}}\right)$ to the soil as the Ni85 treatment (Table 3).

The $\mathrm{N}$ use efficiency indexes (NPP, NAE, $\mathrm{N}_{\mathrm{m}} \mathrm{AE}, \mathrm{NRE}$ and $\mathrm{N}_{\mathrm{m}} \mathrm{RE}$ ) also showed significant differences between the treatments of both crops $(p<0.001$, Figure 2a-d). The NPP in lettuce ranged between 25.21 gDMY g ${ }^{-1} \mathrm{~N}$ in Ni85 to 6.15 in DG-N170+170 gDMY g ${ }^{-1} \mathrm{~N}$, and kale ranged between $42.9710 .87 \mathrm{gDMY} \mathrm{g}^{-1} \mathrm{~N}$ in the same treatments. The NPP of Ni85 of both crops was significantly higher than the other treatments, and this treatment had values similar to those referred to in other works [32]. The treatments with the significantly lowest NPP were those with the highest amount of DG application, the DG-N170+85 and the DG-N170+170. The NAE was a small proportion of the NPP of each treatment of both crops; for lettuce, NAE was 33\% of NPP in Ni85 treatment and 7\% in DG-N170+85. For kale, NAE ranged from $34 \%$ of NPP in Ni85 treatment to $\cong 2 \%$ in the DG-N85. In lettuce, the NAE of Ni85 (8.41) and of the DG-N85+Ni60 (6.60) was significantly higher than the NAE of the other treatments. The significantly lowest NAE values of lettuce were observed in the DG-N170+85 (0.50) and the DG-N170+170 (1.39). Regarding the kale crop, the significantly higher NAE values were observed in the Ni85 (14.76), in the DG-N85+Ni60 (10.37) and the DG-N170+Ni60 (9.75). The $\mathrm{N}_{\mathrm{m}} \mathrm{AE}$ index showed the same trend as the NAE for both crops. However, for lettuce, the best behaviour was observed for the treatments with the application of DG together with inorganic mineral fertilisation and for kale in addition to those treatments with higher application rates of DG DG-N170+85 and DG-N170+170. 
The more profound decrease of the NRE index observed in the DG treatments as the only source of $\mathrm{N}$ occurred in both crops. The NRE of Ni85 treatment was significantly higher in lettuce $(29 \%)$, and kale $(40 \%)$ compared with other treatments and were similar to those found for cabbage in [33]. In both crops, the significantly lowest values were for lettuce in the DG-N85 $(-0.05 \%)$ and the DG-N170+85 $(-0.58 \%)$ and kale in the DG-N170 $(-2.22 \%)$ and the DG-N85 $(0.56 \%)$. For lettuce, the $\mathrm{N}_{\mathrm{m}} \mathrm{RE}$ also had the lowest, and even negative values in the DG treatments with Nm application rates $\left(\mathrm{kg} \mathrm{Nm} \mathrm{ha}^{-1}\right)$ of 30 (DG-N85- $\mathrm{N}_{\mathrm{m}} \mathrm{RE}$ of $-0.15 \%$ ), 59 (DG-N170- $\mathrm{N}_{\mathrm{m}} \mathrm{RE}$ of $4.27 \%$ ) and 89 (DG-170+85- $\mathrm{N}_{\mathrm{m}} \mathrm{RE}$ of $-1.65 \%$ ), while the treatment with $119 \mathrm{~kg} \mathrm{~N}_{\mathrm{m}}$ ha $^{-1}$ (DG-N170+170- $\mathrm{N}_{\mathrm{m}}$ RE of $13.15 \%$ ) showed a $\mathrm{N}_{\mathrm{m}} \mathrm{RE}$ higher and similar to the treatments with the DG and mineral $\mathrm{N}$ fertilisation $\left(\mathrm{N}_{\mathrm{m}} \mathrm{RE}\right.$ ranges between 21.98 and 30.27 ) and also to the Ni85- $\mathrm{N}_{\mathrm{m}} \mathrm{RE}$ of $29.10 \%$. For kale, the $\mathrm{N}_{\mathrm{m}} \mathrm{RE}$ showed the same trend, but the lowest $\mathrm{N}_{\mathrm{m}} \mathrm{RE}$ values were observed only in DG-N85- $\mathrm{N}_{\mathrm{m}} \mathrm{RE}$ of $3.00 \%$ and in DG-170- $\mathrm{N}_{\mathrm{m}}$ RE of $-11.77 \%$ and the highest in the DG-N170+Ni60- $\mathrm{N}_{\mathrm{m}}$ RE of $63.05 \%$.

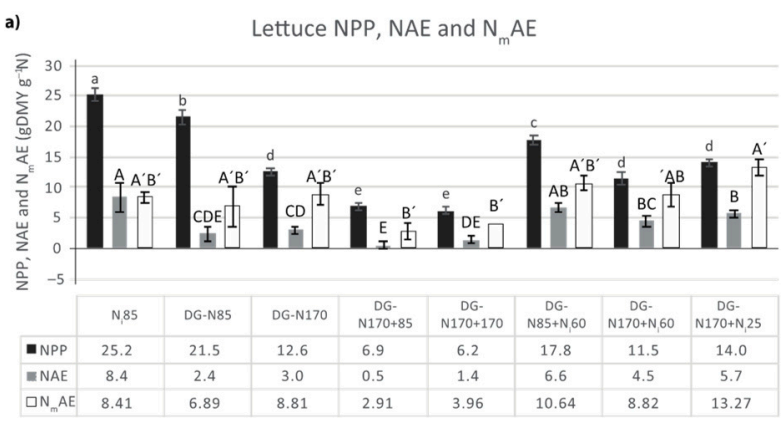

c)

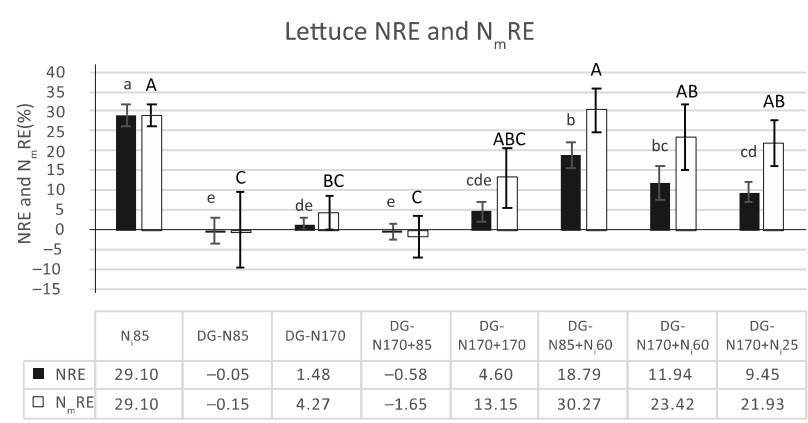

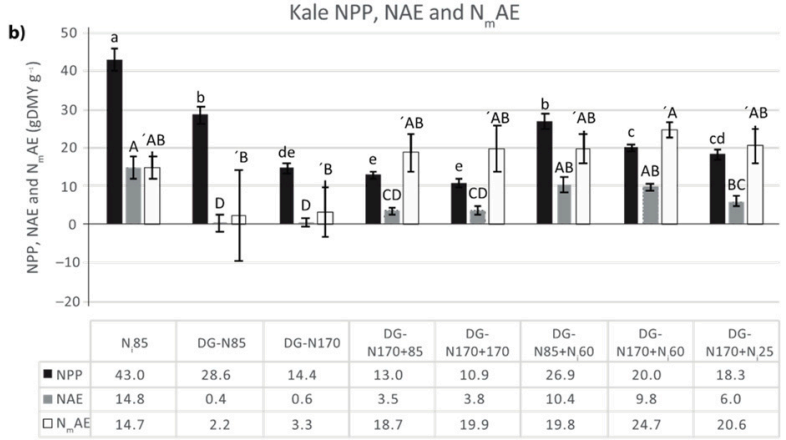

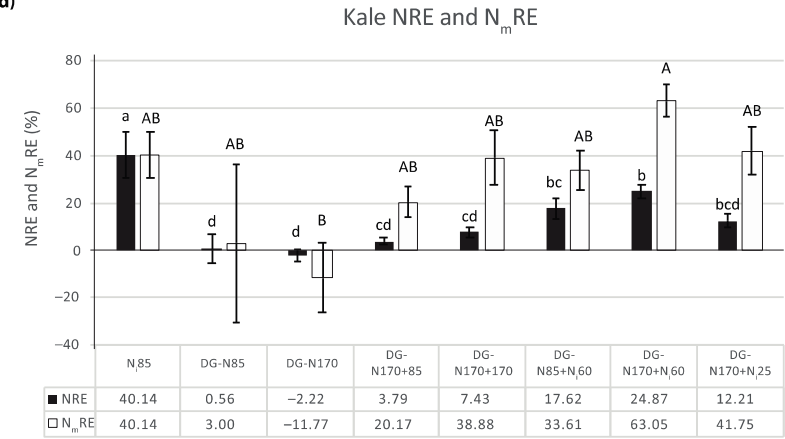

Figure 2. Nitrogen partial productivity (NPP, $g$ DMY $g^{-1} \mathrm{~N}$ ) and nitrogen agronomic efficiency (NAE, and $\mathrm{N}_{\mathrm{m}} \mathrm{AE}, \mathrm{g}$ DMY $\mathrm{g}^{-1} \mathrm{~N}$ ) of (a) lettuce and (b) kale, and nitrogen recovery efficiency (NRE and $\mathrm{N}_{\mathrm{m}} \mathrm{RE}, \%$ ) of (c) lettuce and (d) kale. The data are presented as mean $\pm \mathrm{SE}(n=4)$. According to Duncan's multiple range test, different letters above the columns indicate statistically significant differences among the treatments for each nitrogen use efficiency indexes $(p<0.05)$.

\subsection{Soil Properties}

Overall, after the second crop cycle, the physical and chemical properties of the soils changed significantly compared with the first crop cycle (Table 5). The $\mathrm{pH}$ increased from 6.1 to 6.3 , the OM from 6.1 to $7.6 \%$, and the total $\mathrm{N}$ from 2.7 to $3.2 \mathrm{mg} \mathrm{kg}^{-1}$. The soil properties that decreased significantly after the second crop cycle were the EC from 0.13 to $0.09 \mathrm{dS} \mathrm{m}^{-1}$. The soil EC was low $\left(<0.40 \mathrm{dS} \mathrm{m}^{-1}\right.$, [18]) and was similar in the treatments fertilised with digestates and with the $\mathrm{N}$ mineral fertilisation. The exchangeable bases also decreased significantly at the end of the second crop cycle, $\mathrm{K}^{+}$from 1.44 to $1.33 \mathrm{cmol}_{\mathrm{c}} \mathrm{kg}^{-1}$, $\mathrm{Ca}^{2+}$ from 7.45 to $5.53 \mathrm{cmol}_{\mathrm{c}} \mathrm{kg}^{-1}$ and $\mathrm{Na}^{+}$from 0.04 to $0.01 \mathrm{cmol}_{\mathrm{c}} \mathrm{kg}^{-1}$. 
Table 5. Changes in the soil properties after the lettuce and the kale crop cycles obtained by the ANCOVA treatment.

\begin{tabular}{|c|c|c|c|c|c|c|c|c|}
\hline & $\mathrm{pH}$ & EC & MO & $\mathbf{N t}$ & $\mathbf{K}$ & $\mathrm{Ca}$ & Mg & $\mathrm{Na}$ \\
\hline${ }^{1}$ Year & & $\mathrm{dSm}^{-1}$ & $\%$ & & & $\mathrm{cmol}_{\mathrm{c}} \mathrm{kg}^{-1}$ & & \\
\hline Lettuce-May_2020 & 6.1 & 0.13 & 6.1 & 2.7 & 1.44 & 7.45 & 1.22 & 0.04 \\
\hline Kale-March_2021 & 6.3 & 0.09 & 7.6 & 3.2 & 1.03 & 5.53 & 1.17 & 0.01 \\
\hline Significant & $p<0.001$ & $p<0.001$ & $p<0.001$ & $p<0.001$ & $p<0.001$ & $p<0.001$ & $p>0.05$ & $p<0.001$ \\
\hline \multicolumn{9}{|l|}{1 Treatment } \\
\hline Control & $6.2 \mathrm{~cd}$ & $0.09 \mathrm{~b}$ & $6.1 \mathrm{c}$ & $2.5 \mathrm{c}$ & $1.23 \mathrm{bcd}$ & $6.50 \mathrm{ab}$ & $0.95 \mathrm{de}$ & $0.020 \mathrm{~d}$ \\
\hline Ni85 & $5.8 \mathrm{f}$ & $0.13 \mathrm{a}$ & $5.6 \mathrm{c}$ & $2.4 \mathrm{c}$ & $1.02 \mathrm{e}$ & $5.99 \mathrm{~b}$ & $0.84 \mathrm{e}$ & $0.021 \mathrm{~cd}$ \\
\hline DG-N85 & $6.3 \mathrm{c}$ & $0.09 \mathrm{~b}$ & $6.1 \mathrm{c}$ & $2.8 \mathrm{bc}$ & $1.21 \mathrm{~cd}$ & $6.79 \mathrm{a}$ & $1.09 \mathrm{~cd}$ & $0.026 \mathrm{bcd}$ \\
\hline DG-N170 & $6.4 \mathrm{~b}$ & $0.10 \mathrm{~b}$ & $7.7 \mathrm{a}$ & $2.9 \mathrm{abc}$ & $1.35 \mathrm{abc}$ & $6.50 \mathrm{ab}$ & $1.23 \mathrm{c}$ & $0.030 \mathrm{ab}$ \\
\hline DG-N170+85 & $6.5 \mathrm{a}$ & $0.12 \mathrm{a}$ & $7.5 \mathrm{ab}$ & $3.4 \mathrm{a}$ & $1,43 \mathrm{a}$ & $6.76 \mathrm{a}$ & $1.51 \mathrm{~b}$ & $0.034 \mathrm{a}$ \\
\hline DG-N170+170 & $6.5 \mathrm{a}$ & $0.13 \mathrm{a}$ & $7.6 \mathrm{a}$ & $3.3 \mathrm{ab}$ & $1.36 \mathrm{a}$ & $6.96 \mathrm{a}$ & $1.72 \mathrm{a}$ & $0.034 \mathrm{a}$ \\
\hline DG-N85+Ni60 & $6.0 \mathrm{e}$ & $0.09 \mathrm{~b}$ & $7.2 \mathrm{ab}$ & $2.9 \mathrm{abc}$ & $1.10 \mathrm{de}$ & $6.01 \mathrm{~b}$ & $1.07 \mathrm{~cd}$ & $0.026 \mathrm{bcd}$ \\
\hline DG-N170+Ni60 & $6.1 \mathrm{~d}$ & $0.10 \mathrm{~b}$ & $7.7 \mathrm{a}$ & $3.4 \mathrm{ab}$ & $1.21 \mathrm{~cd}$ & $6.04 \mathrm{~b}$ & $1.14 \mathrm{c}$ & $0.028 \mathrm{abc}$ \\
\hline DG-N170+Ni25 & $6.3 \mathrm{c}$ & $0.10 \mathrm{~b}$ & $6.4 \mathrm{bc}$ & $2.8 \mathrm{abc}$ & $1.21 \mathrm{~cd}$ & $6.87 \mathrm{a}$ & $1.23 \mathrm{c}$ & $0.028 \mathrm{abc}$ \\
\hline Significant & $p<0.001$ & $p<0.001$ & $p<0.01$ & $p<0.001$ & $p<0.001$ & $p<0.001$ & $p<0.001$ & $p<0.001$ \\
\hline $\begin{array}{c}\text { Interaction } \\
\text { Year X Treatment }\end{array}$ & $p<0.001$ & $p<0.001$ & $p>0.05$ & $p>0.05$ & $p<0.01$ & $p<0.01$ & $p<0.001$ & $p<0.001$ \\
\hline
\end{tabular}

1_ANCOVA treatment. Comparisons of the changes in soil properties between the two crop cycles and between the treatments. According to LSD multiple range test, different letters in the columns indicate statistically significant differences among the treatments for each soil property $(p<0.05)$.

All soil properties changed significantly regarding the changes between the treatments $(p<0.001)$. The treatments with the application of digestate at an $\mathrm{N}$ rate of $170+85$ and $170+170 \mathrm{~kg} \mathrm{ha}^{-1}$ showed the highest values of $\mathrm{pH}(6.5)$, and on the contrary, the application of mineral $\mathrm{N}$ (Ni85) gives the lowest $\mathrm{pH}$ value (5.8). The treatments Ni85, DG-N170+85 and DG-N170+170, showed the highest values of the EC $\left(\approx 0.13 \mathrm{dS} \mathrm{m}^{-1}\right)$, and in the other treatments, the EC ranged between 0.10 and $0.09 \mathrm{dS} \mathrm{m}^{-1}$. The soil OM showed the highest value (7.7\%) in DG-N170 and DG-N170+Ni60 and the lowest in Ni85 (5.6\%) and both the control and DG-N85 (6.1\%) treatments. The content of total $\mathrm{N}$ in the soil was higher in the treatments DG-N170+85 and DG-N170+Ni60 (3.4 $\left.\mathrm{mg} \mathrm{kg}^{-1}\right)$ and DG-N170+170 ( $3.3 \mathrm{mg} \mathrm{kg}^{-1}$ ) and showed the lowest content in the Ni85 and control treatments (2.4 and $2.5 \mathrm{mg} \mathrm{kg}^{-1}$ respectively). The exchangeable bases $\mathrm{K}^{+}, \mathrm{Ca}^{2+}, \mathrm{Mg}^{2+}$ and $\mathrm{Na}^{+}$, showed the lowest in the control and Ni85 treatments and the highest in the DG-N170+85 and DG-N170+170. For $\mathrm{K}^{+}$, the soil content ranged between 1.02 and $1.23 \mathrm{cmol}_{\mathrm{C}} \mathrm{kg}^{-1}$ in Ni85 and the control treatments to 1.36 and 1.43 in the DG-N170+170 and DG-N170+85. The Ca ${ }^{2+}$ content $\left(\mathrm{cmol}_{\mathrm{C}} \mathrm{kg}^{-1}\right)$ in the soil was 5.99 in the Ni85 and increased to 6.96 (DG-N170+170), 6.87 (DG-N170+Ni25), 6.79 (DG-N85) and 6.76 (DG-N170+85). For the $\mathrm{Mg}^{2+}$, the lowest soil content $\left(\mathrm{cmol}_{\mathrm{C}} \mathrm{kg}^{-1}\right)$ was observed in the Ni85 treatment $(0.84)$ and the highest soil content in the DG-N170+170 treatment (1.72). $\mathrm{Na}^{+}$had the lowest soil content $\left(\mathrm{cmol}_{\mathrm{C}} \mathrm{kg}^{-1}\right)$ in the control (0.02) and the highest in DG-N170+85 and DG-N170+170 (0.034). After the two crop cycles, the amount of soil available $P$ remained high and the crops showed adequate levels of $\mathrm{P}$, in all the treatments. Additionally, the soil content in heavy metals remained low and similar to the control treatment (data not shown).

\section{Discussion}

The fertilisation with digestate had a positive effect on soil properties. The digestates used in this experiment had a beneficial effect as an organic amendment by increasing the content of the soil organic matter and increasing the soil $\mathrm{pH}$ and the exchangeable bases. During the anaerobic digestion, the degradation of more labile fractions (e.g., carbohydratelike molecules) of the organic materials occurred, determining the relative concentration of more recalcitrant organic molecules (lignin and non-hydrolysable lipids). These modifications of the ingested organic material caused a higher degree of biological stability 
of the digestate regarding the starting mixture [2,34]. So, after two crop cycles, the input of this stable organic matter originates an increase of around $26 \%$ in SOM regarding the control treatment. The changes in $\mathrm{pH}$ after fertilisation can be explained, on the one hand, by the increasing effect on soil acidity of the mineral $\mathrm{N}$ fertilisation and the other hand by the decreasing effect on soil acidity provided by the exchangeable bases such as $\mathrm{K}, \mathrm{Ca}$ and $\mathrm{Mg}$ from the digestate. The lowest $\mathrm{pH}$ value observed in the mineral $\mathrm{N}$ fertilisation was probably due to the application of ammonium-based fertilisers. The ammonium salts acidify soils mainly through nitrification in which the $\mathrm{NH}_{4}{ }^{+}$is oxidised into $\mathrm{NO}_{3}{ }^{-}$with the release of $\mathrm{H}^{+}$. However, if the $\mathrm{NO}_{3}{ }^{-}$is taken up by crops, there is no net acidification because the nitrate takes up protons. Acidification only occurs when $\mathrm{NH}_{4}{ }^{+}$is nitrified and $\mathrm{NO}_{3}{ }^{-}$leached $[35,36]$ or if $\mathrm{NH}_{4}{ }^{+}$is taken up by the plant before nitrification occurs and in quantities greater than the accompanying anion. In this case, the soil acidity will result from proton release from roots [37]. Both crops were done in the cold and rainy seasons in our experiment. Thus, some $\mathrm{NO}_{3}{ }^{-}$leaching must have occurred in relation to the $\mathrm{Ni}$ treatment, and the crops might have absorbed some $\mathrm{NH}^{+}$. On the contrary, the increase in soil $\mathrm{pH}$ of the digestates treatments, from 0.1 to $0.3 \mathrm{pH}$ units, compared with the control treatment, can be achieved not only by the primary effect of the $\mathrm{Ca}$ and $\mathrm{Mg}$ content of the digestates but also by the low $\mathrm{N}$ mineralisation rate of the digestates putting into soil solution low amounts of $\mathrm{NH}_{4}{ }^{+}$.

Since the experiments were done in a high fertility soil but with $\mathrm{N}$ provided through different sources, the changes of biomass and RY observed in both crops will be a consequence of the differences in $\mathrm{N}$ availability provided through different sources: mineral fertilisation or digestate application. The decrease of biomass and the relative yield of lettuce and kale with the application of digestate as the only source of $\mathrm{N}$ can be explained by the low mineralisation of the digestate. As referred above, the high stability of the OM in the digestate caused a low mineralisation rate and, therefore a low rate of mineral $\mathrm{N}$ release. Therefore, the organic $\mathrm{N}(\mathrm{NO})$ ratio in relation to the total $\mathrm{N}(\mathrm{TKN})$ in the digestate is a relevant index to evaluate its $\mathrm{N}$ availability. The ratio NO:TKN of DGL was 0.65, and DGK was 0.81 . High NO:TKN values indicate lower $\mathrm{N}$ availability from the digestates since more $\mathrm{N}$ is in organic forms with a low mineralisation rate.

So, the higher NO:TKN of DGK compared with DGL and a low mineralisation rate of both digestates can explain the more profound decrease observed in the kale biomass and RY compared with the lettuce. Thus, the net $\mathrm{N}$ release of the digestate was related to their intrinsic properties, such as the mineral $\mathrm{N}$ content and size of the mineralisable fraction, as also observed by Rigby and Smith [38]. These authors also observed that the capacity of the soil type to process and turnover digestate $\mathrm{N}$ is also a factor affecting soil $\mathrm{N}$ availability. The $\mathrm{N}$ efficiency indexes NPP, NAE and $\mathrm{N}_{\mathrm{m}} \mathrm{AE}$ also showed that the soil and the mineral fertiliser provided the primary source of $\mathrm{N}$ to crops uptake. The proportion of the NAE regarding the NPP showed a decrease in the DG treatments compared with the Ni and the DG-N+Ni treatments. So, the $\mathrm{N}$ availability from the digestate should be impaired by both a low mineralisation rate of the digestate (stable organic matter) and soil $\mathrm{N}$ immobilisation of the $N_{m}$ from the DG. The significant decrease of the $N_{m} A E$ and $N_{m} R E$ in the DG treatments as the only source of $\mathrm{N}$ to crops strengthens the hypothesis of a net soil immobilisation of the $\mathrm{N}$ mineral fraction released by the digestates. This immobilisation will impair the $\mathrm{N}$ uptake by the vegetable crops and the $\mathrm{NH}_{4}{ }^{+}$nitrification and can partially explain the increase in the $\mathrm{pH}$ values in the DG treatments. In addition, the $\mathrm{N}_{\mathrm{m}} \mathrm{RE}$ showed the higher values in the $\mathrm{Ni}$ and DG+Ni treatments and the lowest, even negative values, in the DG treatments. Our hypothesis highlights the poor uptake/availability of the mineral $\mathrm{N}$ of the DG even in treatments with the same amount of $\mathrm{Nm}$ applied as in the treatment with mineral fertilisation $\left(85 \mathrm{~kg} \mathrm{ha}^{-1}\right)$. The fact that the two vegetable crops were done in rainy and cold months can also contribute to the decrease of the mineralisation rate of the DG. Albuquerque et al. [8] also observed a decrease in the fertilising capacity of the digestate in autumn-winter compared with spring-summer horticultural crops. They observed that the available $\mathrm{N}$ fraction of the digestate in the winter crops could be easily lost by 
leaching, and the low temperature slows the rate of microbially mediated processes. For the reasons mentioned above, the low $\mathrm{N}$ availability for the vegetable crops, provided by the digestate, advises the need of supplemented its use with a mineral $\mathrm{N}$ fertiliser to maintain the crop yields. This experiment showed that the amount of mineral $\mathrm{N}$ fertiliser needed is dependent on the ratio NO:TKN of the digestate. Higher ratios needed more mineral $\mathrm{N}$ to maintain the crop yields similar to those obtained through the mineral $\mathrm{N}$ fertilisation. The fertilisation with a digestate low in available $\mathrm{N}$, supplemented with mineral $\mathrm{N}$, was also reported by Sienkiewicz et al. [39]. These authors observed a significant increase in the $\mathrm{N}$ content of the crop biomass compared with the treatments with the digestate as the only source of N. Moreover, the combination of digestate and mineral $\mathrm{N}$ is advisable mainly for crops with short-term $\mathrm{N}$ demand [40], as is the case of the vegetable crops used in this experiment. Additionally, the results of this experiment are in accordance with other works reporting that the combination of organic and mineral fertilisers, contribute to achieving the goals of maintaining or increasing the yields and at the same time built-up the soil organic matter, e.g., [41].

As future remarks, the evaluation of the soil microbial communities and the activities of the enzymes, namely those of the carbon cycle in the different treatments, will allow for a better understanding of the SF behaviour in soils.

\section{Conclusions}

The digestate used in the fertilisation of the vegetable crops showed a beneficial effect as a soil organic amendment increased the soil's carbon stock. The digestate contributed not only to the increase of the soil organic matter but also to raising the soil $\mathrm{pH}$ and increasing the exchangeable bases, giving better conditions for crop growth. However, digestate as the only source of nitrogen to crops proved to have constraints. After the anaerobic digestion of the bio-waste, the organic matter composition of the digestate changed to a more stable composition in relation to the initial mixture. Consequently, the solid fraction of the digestates had a high proportion of $\mathrm{N}$ in organic forms, which also had low mineralisation rates. In addition, the net release of $\mathrm{N}$ to crops was also impaired by soil immobilisation of the mineral $\mathrm{N}$ released by the digestate. So, for autumn-winter vegetable crops, we observed that the fertilisation with digestate should be done together with the application of mineral $\mathrm{N}$. The content of the digestate in organic $\mathrm{N}(\mathrm{NO})$ in relation to total $\mathrm{N}$ (TKN) can be an index to assess the $\mathrm{N}$ efficiency used by the crop. In order to maintain the same biomass production as the mineral $\mathrm{N}$ fertilisation $\left(85 \mathrm{~kg} \mathrm{Ni} \mathrm{ha}^{-1}\right)$, the following fertilisation can be advised: (1) when the ratio NO:TKN is around 0.65 , the fertilisation can be done with $170 \mathrm{~kg} \mathrm{~N} \mathrm{ha}^{-1}$ provided by the digestate plus $25 \mathrm{~kg} \mathrm{~N} \mathrm{ha}^{-1}$ provided by the mineral $\mathrm{N}$ fertilisation, however, (2) when the ratio is higher, around 0.80 , the fertilisation can be done with $85 \mathrm{~kg} \mathrm{~N} \mathrm{ha}^{-1}$ provided by the digestate plus $60 \mathrm{~kg} \mathrm{~N}^{-1}$ provided by the mineral $\mathrm{N}$ fertilisation. In both cases, the anaerobic digestion provided a digestate with a positive fertiliser effect, not only as an organic amendment but also saving mineral $\mathrm{N}$ fertilisers and at the same time provided green energy through biogas production, saving fossil energy consumption.

Author Contributions: Conceptualisation, C.H. and J.P.C.; methodology, C.H. and J.P.C.; performing the experiments, C.H. and J.P.C.; analysing the data, C.H.; writing, C.H. All authors have read and agreed to the published version of the manuscript.

Funding: This research was funded by the project INTERREG 0745_SYMBIOSIS_II_3_E.

Institutional Review Board Statement: Not applicable.

Informed Consent Statement: Not applicable.

Data Availability Statement: The data that support the findings of this study are available upon reasonable request. 
Acknowledgments: The authors gratefully acknowledge support with the laboratory analysis and with the experiment maintenance to Marta Batista, Ângela Antunes, Isabel Dias and Abel Veloso, and Cristina Canavarro for advisement on data analysis.

Conflicts of Interest: The authors declare no potential conflict of interest.

\section{References}

1. Tani, M.; Sakamoto, N.; Kishimoto, T.; Umetsu, K. Utilization of anaerobically digested dairy slurry combined with other wastes following application to agricultural land. Int. Congr. Ser. 2006, 1293, 331-334. [CrossRef]

2. Tambone, F.; Genevini, P.; D'Imporzano, G.; Adani, F. Assessing amendment properties of digestate by studying the organic matter composition and the degree of biological stability during the anaerobic digestion of the organic fraction of MSW. Bioresour. Technol. 2009, 100, 3140-3142. [CrossRef] [PubMed]

3. International Energy Agency. Outlook for biogas and biomethane: Prospects for Organic Growth. World Biogas Summit, 6th July 2021. Available online: https://world-biogas-summit.com/wp-content/uploads/2021/07/Mr.-Sadamori-IEA_Biomethane.pdf (accessed on 19 November 2021).

4. International Energy Agency. Outlook for Biogas and Biomethane: Prospects for Organic Growth. World Energy Outlook Special Report 2020. IEA, Paris. Available online: https://www.iea.org/reports/outlook-for-biogas-and-biomethane-prospects-fororganic-growth/annex (accessed on 19 November 2021).

5. García-Sánchez, M.; Siles, J.A.; Cajthaml, T.; García-Romera, I.; Tlustoš, P.; Száková, J. Effect of digestate and fly ash applications on soil functional properties and microbial communities. Eur. J. Soil Biol. 2015, 71, 1-12. [CrossRef]

6. Muscolo, A.; Settineri, G.; Papalia, T.; Attinà, E.; Basile, C.; Panuccio, M.R.S. Anaerobic co-digestion of recalcitrant agricultural wastes: Characterizing of biochemical parameters of digestate and its impacts on soil ecosystem. Sci. Total Environ. 2017, 586, 746-752. [CrossRef] [PubMed]

7. Panuccio, M.R.; Romeo, F.; Mallamaci, C.; Muscolo, A. Digestate Application on Two Different Soils: Agricultural Benefit and Risk. Waste Biomass Valoriz. 2021, 12, 4341-4353. [CrossRef]

8. Alburquerque, J.; de la Fuente, C.; Campoy, M.; Carrasco, L.; Nájera, I.; Baixauli, C.; Caravaca, F.; Roldan, A.; Cegarra, J.; Bernal, M.P. Agricultural use of digestate for horticultural crop production and improvement of soil properties. Eur. J. Agron. 2012, 43, 119-128. [CrossRef]

9. Möller, K.; Müller, T. Effects of anaerobic digestion on digestate nutrient availability and crop growth: A review. Eng. Life Sci. 2012, 12, 242-257. [CrossRef]

10. Riva, C.; Orzi, V.; Carozzi, M.; Acutis, M.; Boccasile, G.; Lonati, S.; Tambone, F.; D’Imporzano, G.; Adani, F. Short-term experiments in using digestate products as substitutes for mineral $(\mathrm{N})$ fertilizer: Agronomic performance, odours, and ammonia emission impacts. Sci. Total Environ. 2016, 547, 206-214. [CrossRef]

11. Sogn, T.A.; Dragicevic, I.; Linjordet, R.; Krogstad, T.; Eijsink, V.G.H.; Eich-Greatorex, S. Recycling of biogas digestates in plant production: NPK fertilizer value and risk of leaching. Int. J. Recycl. Org. Waste Agric. 2018, 7, 49-58. [CrossRef]

12. Tambone, F.; Orzi, V.; D’Imporzano, G.; Adani, F. Solid and liquid fractionation of digestate: Mass balance, chemical characterization, and agronomic and environmental value. Bioresour. Technol. 2017, 243, 1251-1256. [CrossRef]

13. Tambone, F.; Orzi, V.; Zilio, M.; Adani, F. Measuring the organic amendment properties of the liquid fraction of digestate. Waste Manag. 2019, 88, 21-27. [CrossRef]

14. IUSS Working Group WRB. World Reference Base for Soil Resources. World Soil Resources Reports No. 103; FAO: Rome, Italy, 2006.

15. Horta, M.C. Normal Climatológica 1986-2015. Posto Meteorológico. Escola Superior Agrária de Castelo Branco; Editor IPCB: Castelo Branco, Portugal, 2016.

16. Olsen, S.R.; Cole, C.V.; Watanabe, F.S.; Dean, L.A. Estimation of Available Phosphorus in Soils by Extraction with Sodium Bicar-Bonate; USDA United States Department of Agriculture, Circular Nr. 939; USDA United States Department of Agriculture: Washington, DC, USA, 1954.

17. Egnér, H.; Riehm, H.; Domingo, W.R. Untersuchungen über die chemische Bodenanalyse als Grundlage für die Beurteilung des Nährstoffzustandes der Böden. II. Chemische Extraktionsmethoden zur Phosphor und Kaliumbestimmung. K. Lantbr. Ann. 1960, 26, 199-215.

18. INIAP. Laboratório Químico Agrícola Rebelo da Silva. Manual de Fertilização das Culturas; INIAP: Lisbon, Portugal, 2006 ; p. 282.

19. Murphy, J.; Riley, J.P. A modified single solution method for the determination of phosphate in natural waters. Anal. Chim. Acta 1962, 27, 31-36. [CrossRef]

20. AFNOR: FD CR 13456. Amendments du Sol et Supports de Culture-Etiquetaje, Spécifications et Listes de Produits; AFNOR Normalisation: Paris, France, 2001.

21. Siebert, S. Quality Requirements and Quality Assurance of Digestion Residuals in Germany. ECN/ORBIT Workshop the Future for Anaerobic Digestion of Organic Waste in Europe, Nuremberg. 2008. Available online: http://www.kompost.de/uploads / media/Quality_Requirements_of_digestion_residu\%20als_in_Germany_text_01.pdf (accessed on 19 November 2021).

22. Ministério da Economia. Decree Law 103/2015-Decreto Lei 103/2015, Diário da República, 1a série no 114-15 junho de 2015; Portuguese legislation; Ministério da Economia: Brasil, Portugal, 2015. 
23. AFNOR: NF U44-051. Amendments Organiques-Dénominations, Specifications et Marquage; AFNOR Normalisation: Paris, France, 2006.

24. Ayers, R.S.; Westcot, D.W. Water Quality for Agriculture, FAO Irrigation and Drainage Pap. 29, Rev. 1; FAO: Rome, Italy, 1985.

25. Voća, N.; Krička, T.; Ćosić, T.; Rupić, V.; Jukić, Ž.; Kalambura, S. Digested residue as a fertilizer after the mesophilic process of anaerobic digestion. Plant Soil Environ. 2005, 51, 262-266. [CrossRef]

26. Möller, K.; Schulz, R.; Müller, T. Substrate inputs, nutrient flows and nitrogen loss of two centralized biogas plants in southern Germany. Nutr. Cycl. Agroecosyst. 2010, 87, 307-325. [CrossRef]

27. Teglia, C.; Tremier, A.; Martel, J.-L. Characterization of Solid Digestates: Part 1, Review of Existing Indicators to Assess Solid Digestates Agricultural Use. Waste Biomass Valorization 2011, 2, 43-58. [CrossRef]

28. García-Albacete, M.; Tarquis, A.M.; Cartagena, M.C. Risk of Leaching in Soils Amended by Compost and Digestate from Municipal Solid Waste. Sci. World J. 2014, 2014, 1-8. [CrossRef]

29. Sveyn, H.; Eder, P. End-of-Waste Criteria for Biodegradable Waste Subjected to Biological Treatment (Compost E Digestate): Technical Proposals, Joint Research Centre Scientific and Policy Reports; Report EUR 26425 EN; European Commission: Brussels, Belgium, 2014 [CrossRef]

30. Walkley, A.; Black, I.A. An examination of the Degtjareff method for determining soil organic matter, and a proposed modification of the chromic acid titration method. Soil Sci. 1934, 37, 29-38. [CrossRef]

31. Deshpande, V.V.; Telang, M.S. Pipet Method of Sedimentation Analysis. Rapid Determination of Distribution of particle Size. Anal. Chem. 1950, 22, 840-841. [CrossRef]

32. Farag, A.A.A.; Abdrabbo, M.A.A.; Abd-Elmoniem, E.M. Using different nitrogen and compost levels on lettuce grown in coconut fiber. J. Hortic For. 2013, 5, 21-28. [CrossRef]

33. Wang, Z.; Li, Y.-K.; Guo, W.-Z.; Xu, Z.-G.; Wang, L.-C.; Ma, L. Yield, nitrogen use efficiency and economic benefits of biochar additions to Chinese Flowering Cabbage in Northwest China. Nutr. Cycl. Agroecosyst. 2019, 113, 337-348. [CrossRef]

34. Provenzano, M.R.; Malerba, A.D.; Pezzolla, D.; Gigliotti, G. Chemical and spectroscopic characterization of organic matter during the anaerobic digestion and successive composting of pig slurry. Waste Manag. 2014, 34, 653-660. [CrossRef] [PubMed]

35. Marschner, P. (Ed.) Marschner's Mineral Nutrition of Higher Plants, 3rd ed.; Academic Press: London, UK, 2012.

36. Goulding, K.W.T. Soil acidification and the importance of liming agricultural soils with particular reference to the United Kingdom. Soil Use Manag. 2016, 32, 390-399. [CrossRef]

37. Lungu, O.I.; Dynoodt, R.F. Acidification From Long-Term Use Of Urea And Its Effect On Selected Soil Properties. Afr. J. Food Agric. Nutr. Dev. 2008, 8, 63-76. [CrossRef]

38. Rigby, H.; Smith, S.R. Nitrogen availability and indirect measurements of greenhouse gas emissions from aerobic and anaerobic biowaste digestates applied to agricultural soils. Waste Manag. 2013, 33, 2641-2652. [CrossRef]

39. Sienkiewicz, S.; Wierzbowska, J.; Kovacik, P.; Krzebietke, S.; Zarczynski, P. Digestate as a substitute of fertilizers in the cultivation of Virginia Fanpetals. Fresenius Environ. Bull. 2018, 27, 3970-3976.

40. Ehmann, A.; Thumm, U.; Lewandowski, I. Fertilizing Potential of Separated Biogas Digestates in Annual and Perennial Biomass Production Systems. Front. Sustain. Food Syst. 2018, 2, 12. [CrossRef]

41. Möller, K. Influence of different manuring systems with and without biogas digestion on soil organic matter and nitrogen inputs, flows and budgets in organic cropping systems. Nutr. Cycl. Agroecosyst. 2009, 84, 179-202. [CrossRef] 